\title{
Dittrichia viscosa L. Ethanolic Extract Based Ointment with Antiradical, Antioxidant, and Healing Wound Activities
}

\author{
Wafa Rhimi ${ }^{10}{ }^{1,2}$, Raoudha Hlel ${ }^{1,2}$, Issam Ben Salem ${ }^{2}$, Abdennacer Boulila ${ }^{3}$, \\ Ahmed Rejeb $^{4}$, and Mouldi Saidi ${ }^{2}$ \\ ${ }^{1}$ Faculté des Sciences de Bizerte, Zarzouna, Université de Carthage, 7021, Tunisia \\ ${ }^{2}$ Laboratory of Biotechnology and Nuclear Technology, National Centre of Nuclear Science and Technology (CNSTN), \\ Sidi Thabet Technopark, 2020 Ariana, Tunisia \\ ${ }^{3}$ Laboratory of Natural Substances LR10INRAP02, National Institute of Research and Physicochemical Analysis, \\ Biotechpole of Sidi Thabet, Ariana 2020, Tunisia \\ ${ }^{4}$ Laboratory of Anatomy Pathology, University of Manouba, National School of Veterinary Medicine, Tunisia \\ Correspondence should be addressed to Wafa Rhimi; wafa_rhimi@hotmail.com
}

Received 18 January 2019; Revised 30 March 2019; Accepted 8 April 2019; Published 22 April 2019

Academic Editor: Gang Liu

Copyright (C) 2019 Wafa Rhimi et al. This is an open access article distributed under the Creative Commons Attribution License, which permits unrestricted use, distribution, and reproduction in any medium, provided the original work is properly cited.

\begin{abstract}
Dittrichia viscosa which belongs to the Asteraceae family is frequently used to treat hematomas and skin disorders in Mediterranean herbal medicine. This study aims to validate its antioxidant effects and its potential on healing wounds. The ethanolic extract of D. viscosa leaves was formulated as $2.5 \%$ and $5 \%(\mathrm{w} / \mathrm{w})$ in ointment bases on the beeswax and sesame oil. During this study, the ethanolic D. viscosa extract, ointments containing $2.5 \%$ and $5 \%$ of $D$. viscosa extract, and the vehiculum were assessed for their total phenol content (TPC), caffeoylquinic acid content (CQC), and antioxidant activities using complementary methods (TAC, the $\mathrm{DPPH}, \mathrm{ABTS}$, FRAP, and the BCB). The effects on wound healing of obtained ointments were evaluated by excision of the wound in a mice model for 12 days. Subsequently, the excised wound areas were measured at the $3^{\text {rd }}, 9^{\text {th }}$, and $12^{\text {th }}$ days. The skin tissues were isolated for histological studies. The ointments containing $D$. viscosa extract (2.5\%,5\%) possessed a considerable TPC, CQC, radical scavenging potential, and antioxidant activities compared to the vehiculum. Treated animals with ointments containing $D$. viscosa extract at $2.5 \%$ and $5 \%$ showed almost and totally healed wounds compared to the vehiculum and control groups, evidenced by good skin regeneration and reepithelialization. The present work showed the role of $D$. viscosa antioxidants exerted by its polyphenolic compounds, in particular, caffeoylquinic acids, in enhancing wound healing.
\end{abstract}

\section{Introduction}

The research to ensure a good quality of wound closure and scarless healing remains a health preoccupation until today $[1,2]$. Recent investigation in wound healing mechanisms has evidenced that reactive oxygen species (i.e., hydroxyl $\mathrm{OH}^{-}$, peroxyl radicals $\mathrm{ROO}^{-}$, and superoxide anion $\mathrm{O}_{2}{ }^{-}$) act as mediator molecules between lymphoid cells and the wound sites as well as defensive molecules against pathogenic microorganisms in the wound area [3,4]. In fact, basal level of reactive oxygen species (ROS) is necessary to regularize the inflammatory response, construction, and relaxation of blood vessels around wound areas [3, 4]. However, an excess of ROS level causes an imbalance between cellular production of free radicals (oxidants), and antioxidant defenses mechanisms, augmentation in inflammatory response, and inhibition of the wound repair $[5,6]$.

Indeed, antioxidants are scavengers molecules which are indispensable for neutralization of free radicals and for remediation of ROS damage during healing process $[3,6]$. In this sense, plants extracts are emerging as a rich source of active compounds (i.e., triterpenes, flavonoids, polyphenolic, and tannins) for their pertinent properties to prevent from (i) accumulation of free radicals, (ii) oxidation of lipid, and (iii) inhibition of inflammatory disease. The use of several medicinal plants was strongly associated to their antioxidant properties. In particular, Asteraceae species plants were 
frequently used in wound healing treatment due to their high amount of phenolic compounds [7].

Among them, Dittrichia viscosa belonging to the genus of Dittrichia produced typical secondary metabolites such as phenolic compounds with antioxidant properties [7-10]. The D. viscosa was investigated against some free radicals (i.e., DPPH and ABTS). Then, some isolated flavonoids from this plant (i.e., sakuranetin, 7-O-methylaromadendrin, and 3acetyl-7-O-methylaromadendrin) have been studied for their anti-inflammatory properties by subcutaneous injection of phospholipase A2 (PLA2) into mouse paws. However, to the best of our knowledge, the data about the antioxidant activities of crude extracts is scanty and there are no previous studies about the wound healing activity of $D$. viscosa ethanolic extract. The high use of this plant in traditional medicine in Mediterranean area explains our interest to suggest the usefulness of the extract of D. viscosa as wound healing ointment. The aims of the present study are to investigate in vitro the antiradical and antioxidant properties of ointments based on ethanolic D. viscosa extract and then to evaluate the potential of these ointments in wound healing in vivo.

\section{Materials and Methods}

2.1. Plant Extraction and Identification of Major Constituents. Fresh leaves of $D$. viscosa were collected from a remote area in Sidi Thabet, province of Ariana, North West of Tunisia. The plant was botanically identified in the Laboratory of Botany and Ornamental Plants, National Institute of Agronomic Research of Tunis. Leaves were air dried and then ground (0.5 $\mathrm{mm}$ ) using blender mill. The powdered leaf was macerated in ethanol $(10: 100, \mathrm{w} / \mathrm{v}(\mathrm{g} / \mathrm{ml}))$ during $48 \mathrm{~h}$. After filtration, the solvent of extract was removed in rotary evaporator (Schwabach, Germany). The dried ethanolic extract was used for all experiments. The constituents of Dittrichia viscosa extract were identified using HPLC-DAD-ESI/MS as previously reported [11], and $20 \mu \mathrm{L}$ of extract at the concentration of $5 \mathrm{mg} / \mathrm{mL}$ was used for high performance liquid chromatography analysis (HPLC) using a chromatograph Alliance e2695 (waters, Bedford, MA, USA) equipped with photodiode array detector (PDA), interfaced with a triple quadruple mass spectrometer (MSD 3100, Waters) and an ESI ion source. The separation was carried out on an RPxTerra MS column $(150 \times 4.6 \mathrm{~mm}$. i.d., $3.5 \mu \mathrm{m}$ particles sizes $)$. The phase mobile composed of water (A) and acetonitrile (B), both containing formic acid $0.1 \%$ with flow rate of 0.5 $\mathrm{mL} / \mathrm{min}$. The following gradient elution was used as follows: 0-40 min, 86 A\%; 40-60 min, 85\% A; 60-75 min, 100\% A; 75$80 \mathrm{~min}, 86 \% \mathrm{~A}$. The mass spectra were acquired over $\mathrm{m} / \mathrm{z}$ 100-1000 amu. The PDA acquisition wavelength was set in 200-800 nm, and the ionization conditions were performed as follows: electrospray voltage on negative mode of the ion source $25 \mathrm{~V}$ and a capillary temperature of $380^{\circ} \mathrm{C}$. Mass Lynx v.4.1 software was used for data acquisition and processing. Identification of the constituents was based on their retention times, UV absorption spectra, and mass spectra data, as well as by comparison with authentic standards if available or literature data.

\subsection{Ointment Preparation}

2.2.1. Formulation of Topical Preparation. Two concentrations of D. viscosa ethanolic extract $(2.5 \%$ and $5 \%(\mathrm{w}: \mathrm{w}))$ were used to formulate ointments according to the method of Alkafafy et al. [12] with a slight modification. Black sesame oil was heated to $100^{\circ} \mathrm{C}$ and ethanolic extract was added and homogenized for 3 min using an Ultra-Turrax homogenizer (T25, IKA Works, Wilmington, NC). Then, the liquefied beewax (10\% of ointment) was added into the mixture and dispersed for 2 min using Ultra-Turrax homogenizer. Finally, obtained ointments were transferred to cool in ambient temperature and stored for all subsequent studies.

In order to evaluate the total phenol content, the caffeoylquinic acid content, and the antiradical and antioxidant potential of samples, ethanolic extract of $D$. viscosa was solubilized in methanol at a concentration of $1 \mathrm{mg} / \mathrm{mL}$, while ointments containing D. viscosa (2.5\% and 5\%) and ointment base (vehiculum) were solubilized in dimethyl sulfoxide (DMSO) at concentration of $10 \mathrm{mg} / \mathrm{mL}$.

2.2.2. Total Phenol Content (TPC). The TPC was determined using the Folin-Ciocalteu assay according to the method of Meda et al. [13]. Briefly, $500 \mu \mathrm{L}$ of each dissolved sample (extract, or ointment) was added to $2.5 \mathrm{~mL}$ of 10 -fold diluted Folin-Ciocalteu reagent. Then, the $2 \mathrm{~mL}$ of saturated sodium carbonate $\left(\mathrm{Na}_{2} \mathrm{CO}_{3}\right)$ solution $(7.5 \%)$ was added to the mixture. The reaction mixtures were kept in the dark for $2 \mathrm{~h}$. After the incubation, the samples absorbance was measured at $760 \mathrm{~nm}$ against the blank (methanol for extract and DMSO for ointments). All assays were conducted in triplicate and the results were averaged. The gallic acid (GAE) was used as the standard and the results were expressed as milligrams of gallic acid equivalent per gram of sample (extract or ointment) (mg GAE/g sample).

2.2.3. Caffeoylquinic Acid Content (CQC). The CQC in all samples was determined with the molybdate colorimetric assay according to the method of Chan et al. [14]. Briefly, $0.3 \mathrm{~mL}$ of appropriate sample solution was added to 2.7 $\mathrm{mL}$ of the molybdate reagent (1.65 g sodium molybdate, 0.8 $\mathrm{g}$ dipotassium hydrogen phosphate, and $0.79 \mathrm{~g}$ potassium dihydrogen phosphate in $100 \mathrm{~mL}$ of deionized water). The reaction mixture was incubated for $10 \mathrm{~min}$, and its absorbance was measured at $370 \mathrm{~nm}$ against a blank sample. The chlorogenic acid (ChlA) was used as the standard and the results were expressed as milligram of ChlA equivalent per gram of sample (extract or ointment) (mg ChlA/g sample).

\subsection{Antiradical and Antioxidant Properties}

2.3.1. Total Antioxidant Capacity (TAC) Method. The total antioxidant capacities of extract and ointments were evaluated using the phosphomolybdenum method described by Prieto et al. [15] with slight modifications. An aliquot of 0.25 $\mathrm{mL}$ sample solution (with concentration that ranged from 0.01 to $1 \mathrm{mg} / \mathrm{mL}$ for extract and from $1 \mathrm{mg}$ to $10 \mathrm{mg} / \mathrm{mL}$ for ointments and vehiculum) was mixed with $0.75 \mathrm{~mL}$ of reagent solution (2.4 M of sulfuric acid, $112 \mathrm{mM}$ of sodium phosphate, 
and $16 \mathrm{mM}$ of ammonium molybdate). Methanol was used as blank. The tubes were capped and incubated in a boiling water bath at $95^{\circ} \mathrm{C}$ for $90 \mathrm{~min}$. After the samples had cooled in room temperature, the absorbance of each sample was measured in spectrophotometer (Milton Roy, New York, USA) at 695 $\mathrm{nm}$. Total antioxidant capacity was expressed as equivalents of ascorbic acid per gram of sample (extract or ointment) (mg AAE/g of sample).

2.3.2. Diphenyl-1-Picrylhydrazyl (DPPH*) Method. The radical scavenging activity of the extracts against $\mathrm{DPPH}^{\bullet}$ free radical was determined by the method of Molyneux et al. [16] with some adjustments. $1 \mathrm{~mL}$ of sample solution (with concentration that ranged from 0.01 to $1 \mathrm{mg} / \mathrm{mL}$ for extract and from $1 \mathrm{mg}$ to $10 \mathrm{mg} / \mathrm{mL}$ for ointments and vehiculum) was combined with methanol $\mathrm{DPPH}^{\bullet}$ solution $(0.1 \mathrm{mM})$. The obtained samples were mixed vigorously and kept in the dark for $60 \mathrm{~min}$.

Subsequently, the absorbance of each sample was measured at $517 \mathrm{~nm}$. The scavenging activity was measured as the decrease in absorbance of the samples versus $\mathrm{DPPH}^{\bullet}$ standard solution. BHT synthetic antioxidant was used as positive control. Results were expressed as radical scavenging activity percentage (\%) of the $\mathrm{DPPH}^{*}$ according to the following equation:

$$
\% \mathrm{DPPH} \text { radical scavenging }=\frac{\left(\mathrm{Abs}_{0}-\mathrm{Abs}_{\mathrm{s}}\right)}{\left.\mathrm{Abs}_{0}\right)} * 100
$$

where $\mathrm{Abs}_{0}$ represents absorbance value of the control and $\mathrm{Abs}_{\mathrm{s}}$ represents absorbance value of sample.

The DPPH radical scavenging activity is shown as $\mathrm{EC}_{50}$ ( $\mu$ g sample/mL) which is the concentration necessary to $50 \%$ reduction of $\mathrm{DPPH}^{\bullet}$ radical.

2.3.3. 2-Azino-Bis-3-Ethylbenzothiazoline-6-Sulfonic Acid (ABTS) Method. The ABTS method is used according to Thaipong et al. [17] for investigating the radical scavenging capacity of each extract. The ABTS ${ }^{\circ}$ solution was prepared by the dissolving of $7 \mathrm{mM} \mathrm{ABTS}^{\bullet}$ in deionized water with potassium persulfate $(2.45 \mathrm{mM})$. The mixture was stranded in the dark at room temperature for 12-16 hours before use. The ABTS ${ }^{\bullet}$ solution was diluted in methanol to an absorbance of 0.7 at $734 \mathrm{~nm}$. For each analysis, a $0.15 \mathrm{~mL}$ aliquot of sample solution (with concentration that ranged from 0.01 to $1 \mathrm{mg} / \mathrm{mL}$ for extract and from $1 \mathrm{mg}$ to $10 \mathrm{mg} / \mathrm{mL}$ for ointments and vehiculum) was added to $2.875 \mathrm{~mL}$ of $\mathrm{ABTS}^{\bullet}$ solution. The samples mixed were incubated for $15 \mathrm{~min}$ in the dark, and the absorbance was measured at $734 \mathrm{~nm}$. BHT was used as standard.

Results were expressed in terms of $\mathrm{EC}_{50}$ ( $\mu \mathrm{g}$ sample/mL), which is the concentration necessary to $50 \%$ reduction of $\mathrm{ABTS}^{\bullet}$ radical.

2.3.4. Ferric Reducing Antioxidant Power (FRAP) Method. The FRAP assay was performed as described by the method of Gouveia et al. [18]. The stock solutions included $300 \mathrm{mM}$ of acetate buffer $\left(3.1 \mathrm{~g}\right.$ of $\mathrm{C}_{2} \mathrm{H}_{3} \mathrm{NaO}_{2} 3 \mathrm{H}_{2} \mathrm{O}$ and $16 \mathrm{~mL}$ of
$\mathrm{C}_{2} \mathrm{H}_{4} \mathrm{O}_{2}$, at $\mathrm{pH}$ 3.6, $10 \mathrm{mM}$ of 2, 4, 6-tripyridyl-s-triazine (TPTZ) solution in $10 \mathrm{mM} \mathrm{HCl}$, and $20 \mathrm{mM} \mathrm{FeCl}_{3} 6 \mathrm{H}_{2} \mathrm{O}$ solution). The FRAP solution was prepared by mixing acetate buffer, TPTZ solution, and $\mathrm{FeCl}_{3} 6 \mathrm{H}_{2} \mathrm{O}$ (10:1:1), and it was then warmed at $37^{\circ} \mathrm{C}$ before using. For each analysis, 0.15 $\mathrm{mL}$ of sample solution with concentration that ranged from 0.01 to $1 \mathrm{mg} / \mathrm{mL}$ for extract and from $1 \mathrm{mg}$ to $10 \mathrm{mg} / \mathrm{mL}$ for ointments and vehiculum was added to $2,85 \mathrm{~mL}$ of the FRAP solution. The absorbance of the reaction mixture was measured at $593 \mathrm{~nm}$ after $30 \mathrm{~min}$ against methanol as blank. Results were expressed as micromole of Trolox equivalent per gram of sample ( $\mu \mathrm{mol} \mathrm{TE/g}$ of sample).

2.3.5. $\beta$-Carotene Linoleic Acid (BCB) Method. The $ß-$ carotene bleaching test was determined according to the method described by Velioglu et al. [19]. This assay based on the measure of the discoloration of $B$-carotene during the oxidation of linoleic acid at $50^{\circ} \mathrm{C}$ of temperature. 0.2 $\mathrm{mg}$ of $ß$-carotene, $20 \mathrm{mg}$ of linoleic acid, and $200 \mathrm{mg}$ of tween 40 were dissolved in $0.5 \mathrm{~mL}$ of chloroform. After removing chloroform, $100 \mathrm{~mL}$ of oxygenated water was added to the final mixture and mixed until homogenization of the emulsion.

$4 \mathrm{~mL}$ of the prepared mixture was added to $0.2 \mathrm{~mL}$ of sample solution (at concentration of $1 \mathrm{mg} / \mathrm{mL}$ for extract and $10 \mathrm{mg} / \mathrm{mL}$ for ointments and vehicle) incubated for $2 \mathrm{~h}$ at $50^{\circ} \mathrm{C}$ in water bath. The BHT was used as a standard. The absorbance of all samples was measured at $470 \mathrm{~nm}$ at two times $(\mathrm{t}=0 \mathrm{~h}$ and $\mathrm{t}=2 \mathrm{~h})$. The antioxidant power of sample was evaluated in terms of bleaching of $\beta$-carotene using the following equation:

$\%$ inhibition of the $B$-carotene bleaching radical

$$
=100 *\left[1-\frac{\left(\mathrm{Abs}_{0}-\mathrm{Abs}_{\mathrm{t}}\right)}{\left(\mathrm{Abs}_{0}(\mathrm{t}=0)-\mathrm{Abs}_{\mathrm{t}}(\mathrm{t}=0)\right)}\right]
$$

where $\mathrm{Abs}_{0}(\mathrm{t}=0)$ represents absorbance value of control at zero time, $\mathrm{Abs}_{0}$ represents absorbance value of control after $2 \mathrm{~h}$ of incubation, $\mathrm{Abs}_{\mathrm{t}}(\mathrm{t}=0)$ represents absorbance value of sample at zero time, and $\mathrm{Abs}_{\mathrm{t}}$ represents absorbance value of sample after $2 \mathrm{~h}$ of incubation.

2.4. Wound Healing Experimental Design. Forty Swiss Webster mice weighing about 20-25g were purchased from the Pasteur Institute of Tunis, Tunisia. Animals were fed with standard pellet diet and were maintained under the following conditions: temperature $\left(25 \pm 3^{\circ} \mathrm{C}\right)$, humidity $(60 \pm 5 \%)$, and 24-h light/dark cycle. All experiments were performed with respect to the Institutional Animal Ethical Committee. Hair was shaved on the dorsal back of mice and disinfected with ethanol (70 \%). Skin wounds of $10 \mathrm{~mm}$ diameter circular full-thickness were made on back of mice using a skin biopsy punch. Animals were randomly allocated into four groups ( $n=10$ each): Group 1: negative control; the group had not received any healing creams/ointments. Group 2: the wounded area was treated with the ointment base (vehiculum). Group 3: the wounded area was treated with ointment of D. viscosa extract $2.5 \%$. Group 4: the wounded 
area was treated with ointment of D. viscosa extract $5 \%$. Ointments and vehiculum were applied daily during 12 postwounding days [12]. At 3, 9, and 12 days of wound healing period, the wound area was measured and the percentage wound contraction was calculated according to the following equation:

$\%$ Wound contraction

$$
=\left(\frac{(\text { Wound area on day"0" }- \text { Wound area on day"n") }}{\text { Wound area on day"0" }}\right)
$$

$$
\times 100
$$

2.5. Histological Studies. On the 3rd, 9th, and 12th days, three mice were randomly taken from each group for the histological examination. The isolated wound tissues from mice skin were formalin fixed and paraffin blocked. Then, $5 \mu \mathrm{m}$ thick transverse incisions were made by means of a microtome fixed blade. Finally, sections were stained with hematoxylin and eosin (HE) and examined by light microscope (Olympus BX51) and photomicrographed using light microscope (Olympus BX51).

2.6. Statistical Analysis. Results were statistically analysed by using one way analysis of variance (ANOVA) test. Significant differences were set at $p<0.05$. The IBM SPSS 22 was used to perform statistical analysis.

\section{Results and Discussion}

3.1. HPLC-DAD-MS Analysis of D. viscosa Ethanolic Extract. Based on mass spectrum, UV spectra, and retention time of each peak of HPLC-PDA-ESI-MS/MS data, 29 phenolics were identified in ethanol extract of $D$. viscosa (Table 1 ).

The dicaffeoylquinic isomers (i.e., chlorogenic acid, 1, 3O-dicaffeoylquinic acid, 3, 4 dicaffeoylquinic acid, 3, 5dicaffeoylquinic acid, 1, 5-Di-caffeoylquinic acid, and 4, 5dicaffeoylquinic acid) and quercetin derivatives (i.e., quercetin-galactosylrhamnoside, rutin-O-pentoside, quercetin3-O-glucoside, rutin, and dihydroquercetin) were the major phenolic compounds. Others minor compounds (i.e., isoorientin, apigenin-glucoside, myricetin, and isorhamnetin-Oglucuronopyranoside) were also found.

To the best of our knowledge the triterpenoid ganoderic acids were identified for the first time in D. viscosa ethanolic extract. In this context, the comparison of our finding with previous results evidenced that the main representative compounds were unchangeable contrary to other minor compounds which are dependent on environmental factors (i.e., territory, temperature, and period of plant collection) and methods of extraction (materials, solvent, and extraction time) $[11,30]$.

3.2. Contents of Total Phenolics and Caffeoylquinic Acid. The TPC and CQC of D. viscosa ethanolic extract leaves, ointment base, and ointments containing $5 \%$ and $2.5 \%$ of extract have been reported in Table 2 .
The TPC and CQC of D. viscosa ethanolic extract leaves were comparable to leaves of Asteraceae family plant (i.e., Cynara scolymus L. and Cynara cardunculus) [31-33]. The TPC and CQC values of ointment containing 2.5\% and 5\% of $D$. viscosa ethanolic extract showed that there is no considerable loss in amount of both phenolic and caffeoylquinic acid compounds during the formulation of ointments. In this sense, it has been reported that the CQC are slightly modifiable after heating at temperature of $100^{\circ} \mathrm{C}$ for $5 \mathrm{~min}$ [34].

3.3. Antiradical and Antioxidant Properties. The TAC, The DPPH, ABTS, FRAP, and the BCB of D. viscosa ethanolic extract, ointment base, and ointment containing $5 \%$ and $2.5 \%$ of extract have been represented in Table 3.

The results of antiradical and antioxidants screening of D. viscosa leaves showed that our findings were comparable to other plants of Asteraceae family. In fact, the TAC, $\mathrm{EC}_{50}$ $(\mathrm{DPPH}), \mathrm{EC}_{50}$ (ABTS), FRAP, and BCB values were in the range of other Asteraceae plants from different country where the TAC ranged from 110.03 to $194.64 \mathrm{mg} \mathrm{AAE} / \mathrm{g}$ extract $[35,36]$, and $\mathrm{EC}_{50}(\mathrm{DPPH})$ values ranged from 100 to 250 $\mu \mathrm{g} / \mathrm{mL}$ [37]. $\mathrm{EC}_{50}$ (ABTS) ranged from 180 to $200 \mu \mathrm{g} / \mathrm{mL}$. FRAP values were ranging from 12.083 to $626.783 \mathrm{mg} \mathrm{TE} / \mathrm{g}$ extract [38] and BCB percentage ranged from 34.8 to $75.20 \%$ $[36,39]$.

To the best of our knowledge there is no data on FRAP and BCB method of D. viscosa extracts. However, the TAC, $\mathrm{EC}_{50}(\mathrm{DPPH})$, and $\mathrm{EC}_{50}$ (ABTS) are in good agreement with those of Morocco D. viscosa leaves extracts [40]. Based on those findings the ethanolic D. viscosa exhibited a strong antioxidant activity explained by the high phenolic content, particularly by the highest caffeoylquinic acid content as indicated in Table 2. Previous investigation on plant of Asteraceae family was in relation to the role of polyphenols such as hydroxycinnamic acids (ferulic acid, p-coumaric acid, chlorogenic acid, and caffeic acid) on the antioxidant activity [41, 42]. Other studies confirmed the implication of dicaffeoylquinic derivatives in antioxidant activity and other biological activities [41, 43, 44].

In particular, the high contribution of caffeoyl derivatives in the antioxidant activities of $D$. viscosa was confirmed by Danino et al. [45] who proved that the isolated compound 1, 3-diCQA from $D$. viscosa has the greatest scavenging activity $\mathrm{DPPH}\left(\mathrm{EC}_{50}=40 \mu \mathrm{M}\right)$ and ABTS $\left(\mathrm{EC}_{50}=12 \pm 0.4 \mu \mathrm{M}\right)$ than the trolox standard.

As shown in Table 3, $10 \mathrm{mg}$ of ointments based on D. viscosa extract (2.5 and 5\%) that exhibited excellent antiradical and antioxidant capacity values was comparable to $1 \mathrm{mg}$ of BHT. The antioxidants, ointment samples showed dependence on to the concentration used. The ointment of $D$. viscosa extract (5\%) possessed the high and the total antioxidant capacity comparing to ointment of $D$. viscosa extract (2.5\%) and the base ointment, evidenced by its strongest radical scavenging activities, ferric reducing as well as BCB inhibition. These findings suggested that the formulation at temperature of $100^{\circ} \mathrm{C}$ did not affect significantly the phenolic composition and did not significantly change the antioxidant activities. Our findings were in agreement with previous 
TABLE 1: Retention time, UV and mass spectral data, and tentative identification of the phenolic components in ethanolic leaves extractof $D$. viscosa.

\begin{tabular}{|c|c|c|c|c|c|c|}
\hline Peak n & $\begin{array}{c}\mathrm{Tr} \\
(\mathrm{min})\end{array}$ & $\begin{array}{l}\lambda \max \\
\max \end{array}$ & $\begin{array}{c}{[\mathrm{M}-\mathrm{H}]^{-}} \\
(\mathrm{m} / \mathrm{z})\end{array}$ & Fragments ions $(\mathrm{m} / \mathrm{z})$ & Tentative of identification & Ref/std \\
\hline 1 & 7.969 & 325 & 353 & $191(100)-161(10)$ & Chlorogenic acid & std \\
\hline 2 & 8.231 & $260-324$ & 375 & $375(20)-191(100)$ & 3-o-Caffeoylquinic acid & std \\
\hline 3 & 9.153 & 293-324- & 543 & $387(50)-191(100)$ & 1,3-O-Dicaffeoylquinic acid & std \\
\hline 4 & 11.405 & 260 & 599 & $467(100)$ & Ganoderic acid $\mathrm{C}_{6}$ & {$[20]$} \\
\hline 5 & 11.694 & 260 & 599 & $467(100)$ & Ganoderic acid $\mathrm{C}_{6}$ & {$[20]$} \\
\hline 6 & 12.243 & 280 & 583 & $467(100)-329(50)$ & Ganoderic acid D & {$[20]$} \\
\hline 7 & 18.712 & $284 \mathrm{sh}$ & 609 & $429(60)-341(20)-301(100)-151(60)$ & $\begin{array}{l}\text { Quercetin- } \\
\text { galactosylrhamnoside }\end{array}$ & {$[21]$} \\
\hline 8 & 19.609 & $\begin{array}{c}260- \\
284 \mathrm{sh}\end{array}$ & 741 & $509(50)-301(100)-241(60)$ & Rutin-O-pentoside & {$[22]$} \\
\hline 9 & 20.751 & $260-331$ & 463 & $301(100)-179(20)-151(30)$ & Quercetin-3-O-glucoside & [23] \\
\hline 10 & 21.158 & $260-332$ & 591 & $301(100)-179(20)-151(30)$ & Rutin & std \\
\hline 11 & 22.791 & $326 \mathrm{sh}$ & 741 & $301(100)-241(20)-151(30)$ & $\begin{array}{l}\text { Quercetin-7-O-xyloside-3-O- } \\
\text { rutinoside }\end{array}$ & {$[23]$} \\
\hline 12 & 23.350 & 327 & 515 & 315(70)-191(40)-179(100) & 3,4-Dicaffeoylquinic acid & std \\
\hline 13 & 25.543 & 327 & 515 & $353(33)-191(100)-179(30)$ & 3,5-Dicaffeoylquinic acid & std \\
\hline 14 & 26.253 & 327 & 677 & $\begin{array}{c}515(15)-353(15)-191(100)-179(40)- \\
135(20)\end{array}$ & $\begin{array}{l}\text { Dicaffeoylquinic acid } \\
\text { glucoside }\end{array}$ & {$[24]$} \\
\hline 15 & 27.015 & 326 & 653 & $\begin{array}{c}515(15)-353(15)-191(100)-179(40)- \\
135(20\end{array}$ & 3, 4,5-Tricaffeoylquinic acid & std \\
\hline 16 & 28.901 & 327 & 515 & $353(30)-191(50)-179(100)-135(40)$ & 1,5-Dicaffeoylquinic acid & std \\
\hline 17 & 29.180 & 327 & 515 & $353(30)-191(50)-179(100)-135(40)$ & 3,5-Dicaffeoylquinic acid & std \\
\hline 18 & 30.525 & 324 & 591 & 509(30)-191(70)-179(100) & 4,5-Dicaffeoylquinic acid & std \\
\hline 19 & 32.022 & 326 & 790 & 591- 405(80)-241(100)-191(60) & Dehydrodimers of caffeic acid & {$[25]$} \\
\hline 20 & 33.291 & $260-327$ & 489 & $241(100)$ & Isoorientin & {$[26]$} \\
\hline 21 & 35.414 & $281-327$ & 489 & $241(100)$ & Isoorientin & {$[26]$} \\
\hline 22 & 36.108 & $292-323$ & 303 & $241(60), 151(100)$ & Dihydroquercetin & {$[21]$} \\
\hline 23 & 39.280 & $280-328$ & 567 & $413(100)$ & Apigenin-glucoside & {$[26]$} \\
\hline 24 & 41.792 & 288 & 493 & $493(100)$ & Myricetin-O-glucuronide & {$[27]$} \\
\hline 25 & 44.651 & $332-288$ & 495 & 493(100) & $\begin{array}{l}\text { Dihydromyricetin-O- } \\
\text { glucuronide }\end{array}$ & {$[28]$} \\
\hline 26 & 46.004 & $\begin{array}{l}260-297- \\
330\end{array}$ & 493 & $\begin{array}{c}493(75)-315(100)-300(50)-271 \\
(80)\end{array}$ & $\begin{array}{l}\text { Isorhamnetin-O- } \\
\text { glucuronopyranoside }\end{array}$ & {$[29]$} \\
\hline 27 & 47.815 & $\begin{array}{l}260-290- \\
331\end{array}$ & 533 & 515(100), $353(80)$ & Dicaffeoylquinic derivatives & std \\
\hline 28 & 51.130 & $260-327$ & 757 & $\begin{array}{c}553(25), 323(20), 203(100), 165 \\
(50), 133(30)\end{array}$ & Caffeoyl-N-tryptophan & {$[26]$} \\
\hline 29 & 52.061 & $260-330$ & 553 & 265(70), 203(100), 163(40) & $\begin{array}{l}\text { Caffeoyl-N-tryptophan- } \\
\text { rhamnoside }\end{array}$ & {$[26]$} \\
\hline
\end{tabular}

TABLE 2: Total phenol content (TPC), caffeoylquinic acid content (CQC) of D. viscosa ethanolic extract, ointment base, and ointment containing $5 \%$ and $2.5 \%$ of extract.

\begin{tabular}{lcccc}
\hline & Ethanolic extract [11] & $\begin{array}{c}\text { Ointment containing } \\
2.5 \% \text { of extract }\end{array}$ & $\begin{array}{c}\text { Ointment containing } \\
5 \% \text { of extract }\end{array}$ & $\begin{array}{c}\text { Ointment base } \\
(\text { vehiculum) }\end{array}$ \\
\hline $\begin{array}{l}\text { TPC (mg GAE/g of } \\
\text { sample) }\end{array}$ & $117.58 \pm 1.29$ & $4.70 \pm 0.19$ & $11.27 \pm 0.121$ & $0.94 \pm 0.05$ \\
$\begin{array}{l}\text { CQC (mg ChlA/g of } \\
\text { sample) }\end{array}$ & $71.85 \pm 0.35$ & $1.85 \pm 0.06$ & $4.77 \pm 0.02$ & $0.00 \pm 0.00$ \\
\hline
\end{tabular}


TABLE 3: Total antioxidant capacity, free radical scavenging (DPPH; ABTS), ferric reducing power, linoleic acid inhibition of D. viscosa ethanolic extract, ointment base, and ointment containing $5 \%$ and $2.5 \%$ of extract.

\begin{tabular}{|c|c|c|c|c|c|}
\hline & $\begin{array}{l}\text { TAC (mg AAE/g of } \\
\text { sample) }\end{array}$ & $\begin{array}{c}E C_{50} D P P H \\
(\mu \mathrm{g} / \mathrm{ml})\end{array}$ & $\begin{array}{c}E C_{50} A B T S \\
(\mu \mathrm{g} / \mathrm{ml})\end{array}$ & $\begin{array}{c}\text { FRAP (mg TE/g of } \\
\text { sample) }\end{array}$ & B-carotene linoleic acid \\
\hline Ethanolic extract & $133.02 \pm 3.1$ & $56.25 \pm 1.2$ & $147.26 \pm 1.5$ & $296.425 \pm 3.3$ & $\begin{array}{c}54.01 \pm 1.4 \\
(\% \mathrm{I} \text { for } 1 \mathrm{mg} / \mathrm{mL})\end{array}$ \\
\hline $\begin{array}{l}\text { Ointment base } \\
\text { (Vehiculum) }\end{array}$ & $1.61 \pm 0.1$ & $7977.00 \pm 225.0$ & $12550 \pm 132$ & $4.37 \pm 0.3$ & $\begin{array}{c}10.85 \pm 1.1(\% \mathrm{I} \text { for } 10 \\
\mathrm{mg} / \mathrm{mL})\end{array}$ \\
\hline $\begin{array}{l}\text { Ointment containing } 2.5 \% \\
\text { of extract }\end{array}$ & $3.41 \pm 0.2$ & $3073.70 \pm 138.8$ & $6290 \pm 183.9$ & $11.69 \pm 0.2$ & $\begin{array}{c}36.22 \pm 0.9 \\
(\% \mathrm{I} \text { for } 10 \mathrm{mg} / \mathrm{mL})\end{array}$ \\
\hline $\begin{array}{l}\text { Ointment containing } 5 \% \\
\text { of extract }\end{array}$ & $7.46 \pm 0.7$ & $1360.50 \pm 90.6$ & $3473.7 \pm 217.5$ & $19.85 \pm 0.4$ & $\begin{array}{c}48.05 \pm 1.8 \\
(\% \mathrm{I} \text { for } 10 \mathrm{mg} / \mathrm{mL})\end{array}$ \\
\hline BHT & - & $26.92 \pm 1.22$ & $42.64 \pm 0.12$ & - & $\begin{array}{c}62.18 \pm 1.6 \\
(\% \text { I for } 1 \mathrm{mg} / \mathrm{mL})\end{array}$ \\
\hline
\end{tabular}

Values expressed are means \pm S.D.

studies that proved that phenolic acids (i.e., gallic, gentisic, protocatechuic, and caffeic acids) in pork lard showed a significant antioxidant activity at $150^{\circ} \mathrm{C}$ [46]. In another study, the addition of antioxidant (i.e., caffeic acid and tyrosol) into refined camellia oil before heating at temperature up to $120^{\circ} \mathrm{C}$ has been protecting the oil from oxidation and molecular changing [47].

3.4. Wound Contraction Ratio. Comparing the three animal groups treated with ointments to the negative control, the wound area decreased significantly $(\mathrm{p}<0.05)$ by the twelfth day. The wound contraction ratio depends on the concentration of extract present in the ointment. In particular, on the 3,9 , and 12 days, the ointment containing D. viscosa $5 \%$ presented the highest wound contraction ratio to animals (Figures 1 and 2).

After 12 days, mice treated with ointments containing $D$. viscosa at $2.5 \%$ and $5 \%$ were totally healed while the vehicle showed a $57 \%$ healing rate (Figure 2). A correlation between the antioxidant activities and wound contraction ratio of animals was observed. Thus, we suggest that antioxidant properties of $D$. viscosa enhanced the wound healing.

3.5. Histological Study. Over 3 days, the tissue sections of all mice groups showed incomplete healing in wound site without significant difference between the groups; this was manifested by the large area of scab tissue. The inflammatory cells and fibrin were accumulated in granulation tissue and fibroblasts were dispersed (Figure 3: C3, V3, O (2.5\%) a, and $\mathrm{O}(5 \%) \mathrm{a})$.

After 9 days, the tissue sections showed obvious difference between groups, though the number of inflammation cells decreased in all groups. Scab area tissue was observed only in the control group and vehicle group. On the other hand, there was great epithelial and collagen fibers organization, remarkable reduction in inflammation cell, and high distribution of fibroplasias. Groups treated with ointments containing $D$. viscosa $(5 \%, 2.5 \%)$ showed greater healing quality compared with other groups manifested by tissue remodeling, the

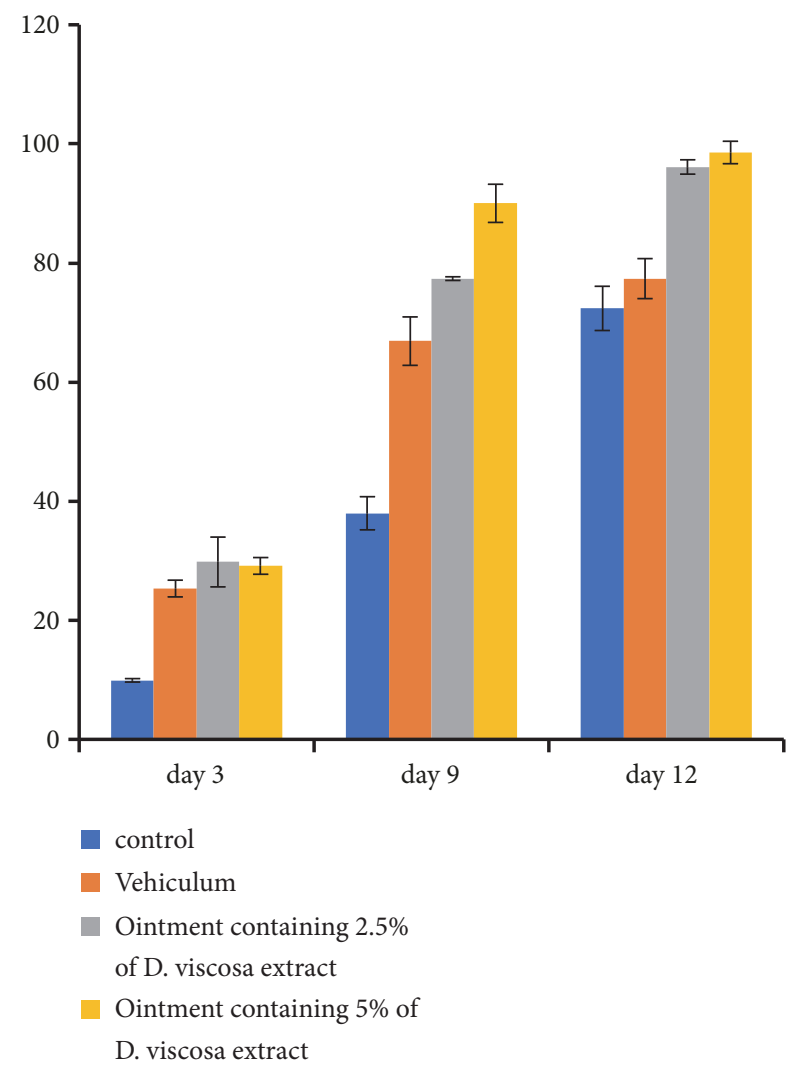

Figure 1: Percentage of wound contraction rate of mice treated with $D$. viscosa $(2.5 \%, 5 \%)$ ointments, positive control (vehicle) and negative control on in vivo wound model.

deposition of collagen in the wound and vessels regression, and mostly restored and keratinized epidermis after 9 days (Figure 3: $\mathrm{O}(5 \%) \mathrm{b}$ and $\mathrm{O}(2.5 \%) \mathrm{b}$ ). With $5 \%$ of $D$. viscosa extract, proliferation of collagens fibers was observed and inflammatory infiltrate was more important than those observed in group treated with $2.5 \%$ of $D$. viscosa extract (Figure 3: O (5\%) b). 

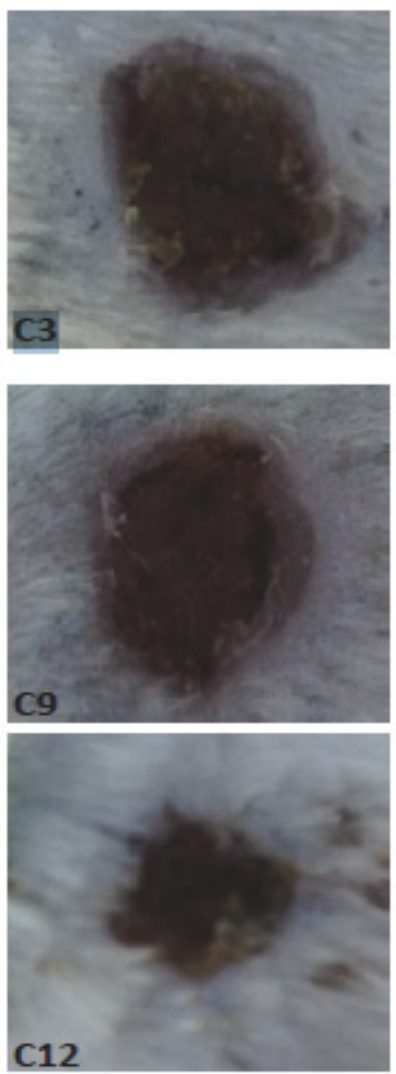
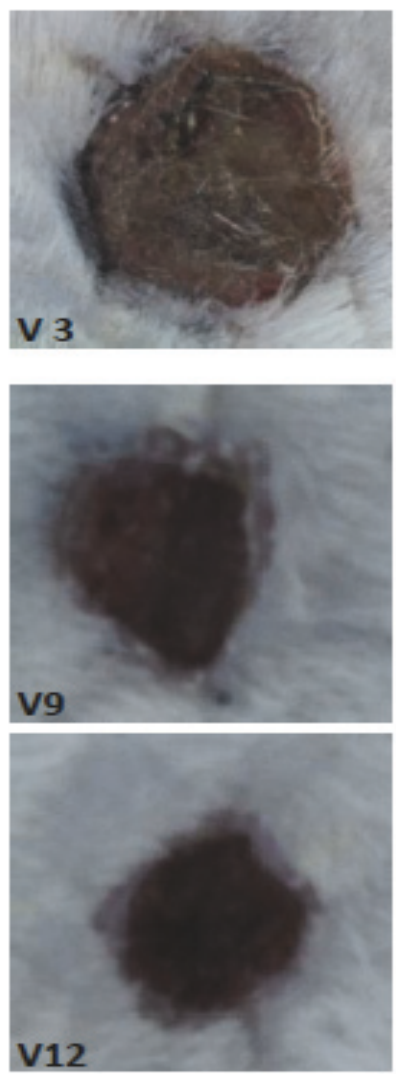
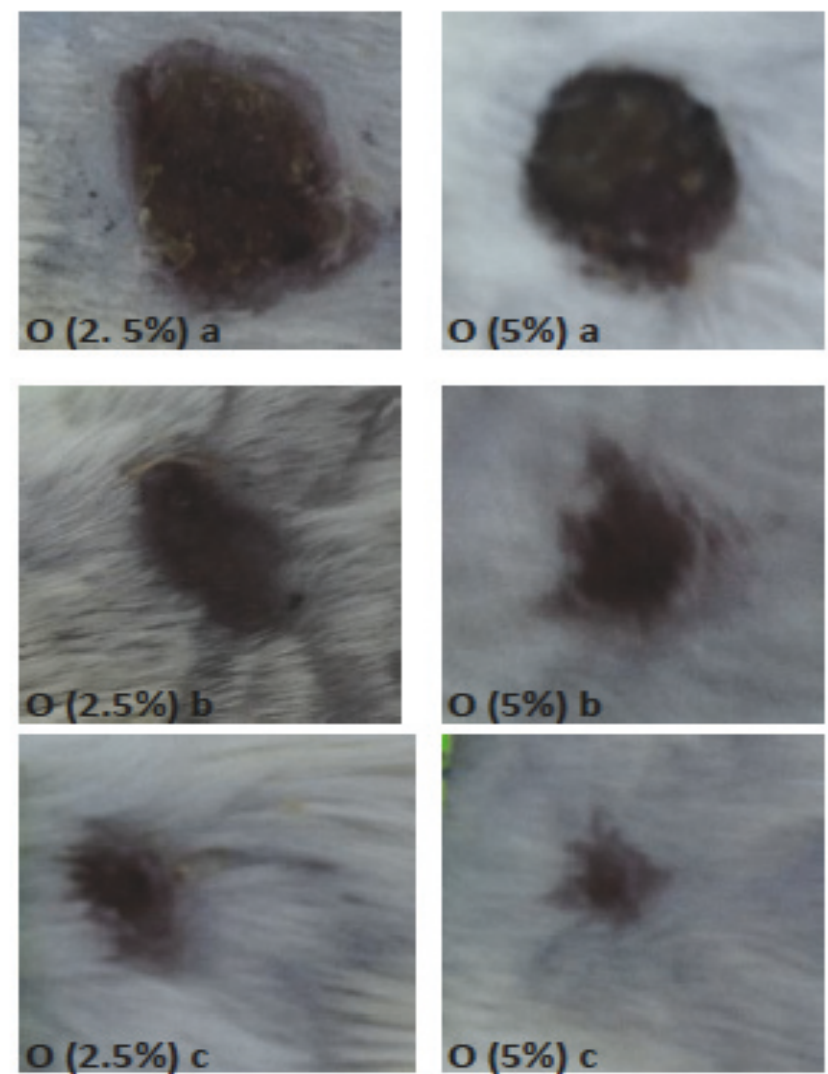

FIGURE 2: Morphological representation on wound contraction of different groups after 3, 9, and 12 days of topical application: $*$ C3: control day $3 ; * \mathrm{C} 9$ : control day $9 ; * \mathrm{C} 12$ : control day $12 ; * \mathrm{~V} 3$ : control day $3 ; * \mathrm{~V} 9$ : control day $9 ; * \mathrm{~V} 12$ : control day 12 ; $\mathrm{O}(2.5 \%)$ a: ointment containing D. viscosa (2.5\%) day 3; O (2.5\%) b: ointment containing D. viscosa (2.5\%) day 9; O (2.5\%) a: ointment containing D. viscosa (2.5\%) day 12 ; O (2.5\%) a: ointment containing D. viscosa $(5 \%)$ day 3 ; O (2.5\%) b: ointment containing D. viscosa (5\%) day 9; O (2.5\%) a: ointment containing D. viscosa (5\%) day 12 .

On day 12, the tissue section showed difference between untreated group (negative control, vehicle) and treated ones with ointments containing $D$. viscosa. Untreated group showed incomplete healing skin (Figure 3: C9, C12, V9, and V12), while group treated with ointment containing $2.5 \%$ revealed quasi-complete healing with maturated granulation tissue and hair follicles as well as highly organized collagen and high distribution of fibroblast cells (Figure 3: O (2.5\%) c). Concerning the group treated with ointment containing $5 \%$ it showed complete healing and full reepithelialization where the numbers of cells and blood vessels were decreased significantly and the collagen fibers had been cross linked (Figure 3: $\mathrm{O}(5 \%) \mathrm{c}$ ).

In general, our findings are in agreement with previous observations that natural antioxidants promote the wound healing $[12,48,49]$. The wound healing is a dynamic interaction between epidermal and dermal cells and extracellular cells, which occurs in three successive phases: inflammation, proliferation, and maturation. In fact, during the inflammatory process the antioxidant altered the migration of the neutrophil to wound area and modulated neutrophil and macrophages influx (i.e., hydrolytic enzymes, reactive oxygen species, and reactive nitrogen species) [50], thus scavenging free radicals and preventing them from damage during proliferation and maturation process. The antioxidants stimulate synthesis of collagen, enhance cell proliferation and the angiogenesis, and promote the reepithelization of the wound [51]. In this context, some individual phenolic compounds (i.e., protocatechuic acid and caffeic acid) have a potential role in cytokines release in wound site, i.e., vascular endothelial growth factor (VEGF) and transforming growth factor beta (TGF-b) which are involved in remodeling the damaged tissue and accelerate the reepithelization [51, 52].

\section{Conclusions}

Our findings suggest that Tunisian D. viscosa could be a consistent source of antioxidant compounds particularly the caffeoylquinic, being able to scavenge free radicals and to prevent from oxidative damage. Subsequently, the investigation on properties of ointment containing D. viscosa leaves showed the potential antioxidant and wound healing effect. Thus, we suggest the role of phenolic compounds in antioxidant and healing wound activities. Hence, this study scientifically opens the perspective to the usefulness of $D$. viscosa as new pharmaceuticals product for oxidative stress 

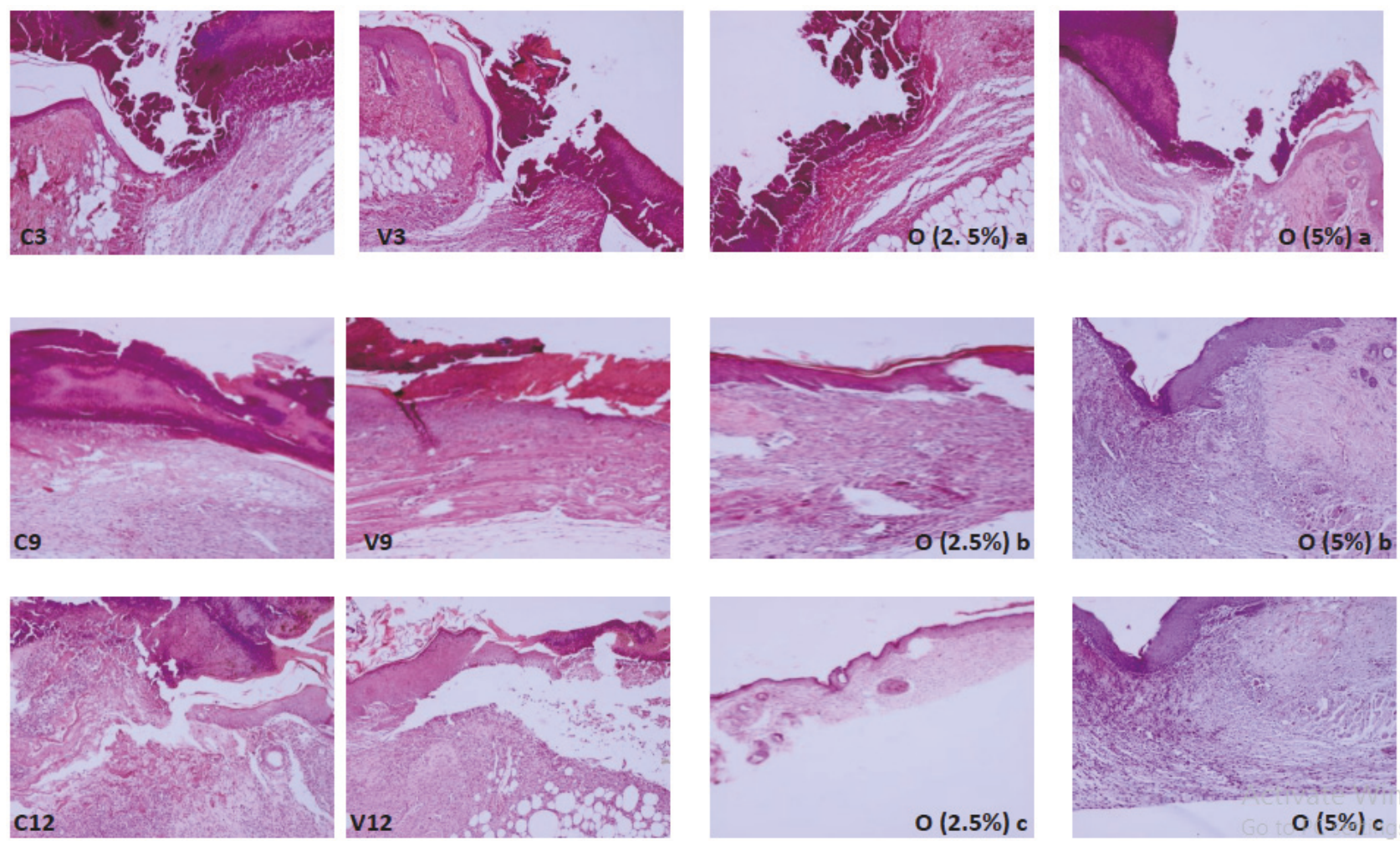

Figure 3: Histological sections of mice of different groups after 3, 9, and 12 days of topical application C3, V3, O (2.5\%) a, and O (5\%) a: complete destruction acute of epiderm, presence of inflammatory cells, and fibrin. C9, C12, V9, and V12: acute inflammation and destruction of epiderm. O (2.5\%) b: proliferation of collagens fibers, inflammatory discreet infiltrate, and reepithelization. O (5\%) b: proliferation of collagens fibers and inflammatory discreet infiltrate more important than those observed in $\mathrm{O}(2.5 \%) \mathrm{b} . \mathrm{O}(2.5 \%)$ c: Complete reepithelization. $\mathrm{O}(5 \%) \mathrm{c}$ : reepithelization and crosslinking of collagen fibers.

and wound healing. However, further in vivo tests should be carried out.

\section{Data Availability}

The data used to support the findings of this study are available from the corresponding author upon request.

\section{Conflicts of Interest}

The authors declare that there are no conflicts of interest regarding the publication of this paper.

\section{Acknowledgments}

This research was funded by the Tunisian Ministry of High Education and Scientific Research.

\section{Supplementary Materials}

Graphic summary description: the ethanolic extract of $D$. viscosa leaves was leaves chemically characterized with HPLC-DAD-MS and it was used to formulate ointments $(5 \%$ and $2.5 \%(\mathrm{w} / \mathrm{w}))$ for healing wound test. Then, the antioxidants and the healing activities of those ointments were evaluated. The results obtained from this study revealed the excellent antioxidant potential of ointments base on ethanolic extract of $D$. viscosa and evidence their role in improving the rate and the quality of wound contraction samples. (Supplementary Materials)

\section{References}

[1] M. Takeo, W. Lee, and M. Ito, "Wound healing and skin regeneration," Cold Spring Harbor Perspectives in Medicine, vol. 5, no. 1, 2015.

[2] C. C. Yates, P. Hebda, and A. Wells, "Skin wound healing and scarring: fetal wounds and regenerative restitution," Birth Defects Research Part C - Embryo Today: Reviews, vol. 96, no. 4, pp. 325-333, 2012.

[3] C. Dunnill, T. Patton, J. Brennan et al., "Reactive oxygen species (ROS) and wound healing: the functional role of ROS and emerging ROS-modulating technologies for augmentation of the healing process," International Wound Journal, vol. 12, no. 6, pp. 1-8, 2015.

[4] M. Mittal, M. R. Siddiqui, K. Tran, S. P. Reddy, and A. B. Malik, "Reactive oxygen species in inflammation and tissue injury," Antioxidants \& Redox Signaling, vol. 20, no. 7, pp. 1126-1167, 2014. 
[5] A. Rahal, A. Kumar, V. Singh et al., "Oxidative stress, prooxidants, and antioxidants: the interplay," BioMed Research International, vol. 2014, Article ID 761264, 19 pages, 2014.

[6] L. A. Pham-Huy, H. He, and C. Pham-Huy, "Free radicals, antioxidants in disease and health," International Journal of Biomedical Science, vol. 4, no. 2, pp. 89-96, 2008.

[7] S. M. F. Bessada, J. C. M. Barreira, and M. B. P. P. Oliveira, "Asteraceae species with most prominent bioactivity and their potential applications: a review," Industrial Crops and Products, vol. 76, pp. 604-615, 2015.

[8] E. Castells, P. P. J. Mulder, and M. Pérez-Trujillo, "Diversity of pyrrolizidine alkaloids in native and invasive Senecio pterophorus (Asteraceae): implications for toxicity," Phytochemistry, vol. 108, pp. 137-146, 2014.

[9] I. Jallali, Y. Zaouali, I. Missaoui, A. Smeoui, C. Abdelly, and R. Ksouri, "Variability of antioxidant and antibacterial effects of essential oils and acetonic extracts of two edible halophytes: Crithmum maritimum L. and Inula crithmoïdes L.," Food Chemistry, vol. 145, pp. 1031-1038, 2014.

[10] C. Zidorn, "Altitudinal variation of secondary metabolites in flowering heads of the Asteraceae: trends and causes," Phytochemistry Reviews, vol. 9, no. 2, pp. 197-203, 2010.

[11] W. Rhimi, I. Ben Salem, D. Immediato, M. Saidi, A. Boulila, and C. Cafarchia, "Chemical composition, antibacterial and antifungal activities of crude Dittrichia viscosa (L.) greuter leaf extracts," Molecules, vol. 22, no. 7, article 942, 2017.

[12] M. Alkafafy, M. Montaser, S. A. El-Shazly, S. Bazid, and M. M. Ahmed, "Ethanolic extract of sharah, Plectranthus aegyptiacus, enhances healing of skin wound in rats," Acta Histochemica, vol. 116, no. 4, pp. 627-638, 2014.

[13] A. Meda, C. E. Lamien, M. Romito, J. Millogo, and O. G. Nacoulma, "Determination of the total phenolic, flavonoid and proline contents in Burkina Fasan honey, as well as their radical scavenging activity," Food Chemistry, vol. 91, no. 3, pp. 571-577, 2005.

[14] E. W. C. Chan, Y. Y. Lim, S. K. Ling, S. P. Tan, K. K. Lim, and M. G. H. Khoo, "Caffeoylquinic acids from leaves of Etlingera species (Zingiberaceae)," LWT- Food Science and Technology, vol. 42, no. 5, pp. 1026-1030, 2009.

[15] P. Prieto, M. Pineda, and M. Aguilar, "Spectrophotometric quantitation of antioxidant capacity through the formation of a phosphomolybdenum complex: specific application to the determination of vitamin E," Analytical Biochemistry, vol. 269, no. 2, pp. 337-341, 1999.

[16] P. Molyneux, "The use of the stable radical diphenylpicrylhydrazyl (DPPH) for estimating antioxidant activity," Songklanakarin Journal of Science and Technology, vol. 26, no. 2, pp. 211-219, 2004.

[17] K. Thaipong, U. Boonprakob, K. Crosby, L. Cisneros-Zevallos, and B. D. Hawkins, "Comparison of ABTS, DPPH, FRAP, and ORAC assays for estimating antioxidant activity from guava fruit extracts," Journal of Food Composition and Analysis, vol. 19, no. 6-7, pp. 669-675, 2006.

[18] S. Gouveia, J. Gonçalves, and P. C. Castilho, "Characterization of phenolic compounds and antioxidant activity of ethanolic extracts from flowers of Andryala glandulosa ssp. varia (Lowe ex DC.) R.Fern., an endemic species of Macaronesia region," Industrial Crops and Products, vol. 42, no. 1, pp. 573-582, 2013.

[19] Y. S. Velioglu, G. Mazza, L. Gao, and B. D. Oomah, "Antioxidant activity and total phenolics in selected fruits, vegetables, and grain products," Journal of Agricultural and Food Chemistry, vol. 46, no. 10, pp. 4113-4117, 1998.
[20] C. S. Yang, J. D. Lambert, J. Ju, G. Lu, and S. Sang, "Tea and cancer prevention: Molecular mechanisms and human relevance," Toxicology and Applied Pharmacology, vol. 224, no. 3, pp. 265-273, 2007.

[21] W. Mullen, T. Yokota, M. E. J. Lean, and A. Crozier, "Analysis of ellagitannins and conjugates of ellagic acid and quercetin in raspberry fruits by LC-MSn," Phytochemistry, vol. 64, no. 2, pp. 617-624, 2003.

[22] A. Vallverdú-Queralt, O. Jáuregui, G. Di Lecce, C. AndrésLacueva, and R. M. Lamuela-Raventós, "Screening of the polyphenol content of tomato-based products through accurate-mass spectrometry (HPLC-ESI-QTOF)," Food Chemistry, vol. 129, no. 3, pp. 877-883, 2011.

[23] M. J. Simirgiotis, J. Benites, C. Areche, and B. Sepu, "Antioxidant capacities and analysis of phenolic compounds in three endemic nolana species by HPLC-PDA-ESI-MS," Molecules, vol. 20, no. 6, pp. 11490-11507, 2015.

[24] L.-Z. Lin and J. M. Harnly, "Identification of the phenolic components of chrysanthemum flower (Chrysanthemum morifolium Ramat)," Food Chemistry, vol. 120, no. 1, pp. 319-326, 2010.

[25] J.-G. Yang and T. Uchiyama, "Dehydrodimers of caffeic acid in the cell walls of suspension-cultured mentha," Bioscience, Biotechnology, and Biochemistry, vol. 64, no. 4, pp. 862-864, 2000.

[26] E. J. Llorent-Martínez, V. Spínola, S. Gouveia, and P. C. Castilho, "HPLC-ESI-MSn characterization of phenolic compounds, terpenoid saponins, and other minor compounds in Bituminaria bituminosa," Industrial Crops and Products, vol. 69, pp. 80-90, 2015.

[27] A. Stalmach, C. A. Edwards, J. D. Wightman, and A. Crozier, "Identification of (Poly)phenolic compounds in concord grape juice and their metabolites in human plasma and urine after juice consumption," Journal of Agricultural and Food Chemistry, vol. 59, no. 17, pp. 9512-9522, 2011.

[28] L. Barros, E. Pereira, R. C. Calhelha et al., "Bioactivity and chemical characterization in hydrophilic and lipophilic compounds of Chenopodium ambrosioides L," Journal of Functional Foods, vol. 5, no. 4, pp. 1732-1740, 2013.

[29] Ł. Marczak, P. Znajdek-Awizeń, and W. Bylka, "The use of mass spectrometric techniques to differentiate isobaric and isomeric flavonoid conjugates from Axyris amaranthoides," Molecules, vol. 21, no. 9, p. 1229, 2016.

[30] I. Trimech, E. K. Weiss, V. S. Chedea et al., "Evaluation of antioxidant and acetylcholinesterase activity and identification of polyphenolics of the invasive weed dittrichia viscosa," Phytochemical Analysis, vol. 25, no. 5, pp. 421-428, 2014.

[31] E. Kollia, P. Markaki, P. Zoumpoulakis, and C. Proestos, "Antioxidant activity of Cynara scolymus L. and Cynara cardunculus L. extracts obtained by different extraction techniques," Natural Product Research (Formerly Natural Product Letters), vol. 31, no. 10, pp. 1163-1167, 2017.

[32] P. Pinelli, F. Agostini, C. Comino, S. Lanteri, E. Portis, and A. Romani, "Simultaneous quantification of caffeoyl esters and flavonoids in wild and cultivated cardoon leaves," Food Chemistry, vol. 105, no. 4, pp. 1695-1701, 2007.

[33] M. Wang, J. E. Simon, I. F. Aviles, K. He, Q.-Y. Zheng, and Y. Tadmor, "Analysis of antioxidative phenolic compounds in artichoke (Cynara scolymus L.)," Journal of Agricultural and Food Chemistry, vol. 51, no. 3, pp. 601-608, 2003.

[34] A. L. Dawidowicz and R. Typek, "Thermal stability of 5-ocaffeoylquinic acid in aqueous solutions at different heating 
conditions," Journal of Agricultural and Food Chemistry, vol. 58, no. 24, pp. 12578-12584, 2010.

[35] S. Albayrak, A. Aksoy, O. Sagdic, and E. Hamzaoglu, "Compositions, antioxidant and antimicrobial activities of Helichrysum (Asteraceae) species collected from Turkey," Food Chemistry, vol. 119, no. 1, pp. 114-122, 2010.

[36] S. Albayrak, A. Aksoy, S. Albayrak, and O. Sagdic, "In vitro antioxidant and antimicrobial activity of some Lamiaceae species," Iranian Journal of Science \& Technology, vol. 37, no. 1, pp. 1-9, 2013.

[37] U. Özgen, A. Mavi, Z. Terzi, M. Coflkun, and Y. Ali, "Antioxidant activities and total phenolic compounds amount of some asteraceae species," Turkish Journal of Pharmaceutical Sciences, vol. 1, pp. 203-216, 2004.

[38] O. Kenny, T. J. Smyth, D. Walsh, C. T. Kelleher, C. M. Hewage, and N. P. Brunton, "Investigating the potential of underutilised plants from the Asteraceae family as a source of natural antimicrobial and antioxidant extracts," Food Chemistry, vol. 161, pp. 79-86, 2014.

[39] A. Akrout, L. A. Gonzalez, H. El Jani, and P. C. Madrid, "Antioxidant and antitumor activities of Artemisia campestris and Thymelaea hirsuta from southern Tunisia," Food and Chemical Toxicology, vol. 49, no. 2, pp. 342-347, 2011.

[40] N. Chahmi, J. Anissi, S. Jennan, A. Farah, K. Sendide, and M. El Hassouni, "Antioxidant activities and total phenol content of Inula viscosa extracts selected from three regions of Morocco," Asian Pacific Journal of Tropical Biomedicine, vol. 5, no. 3, pp. 228-233, 2015.

[41] R. Jaiswal, J. Kiprotich, and N. Kuhnert, "Determination of the hydroxycinnamate profile of 12 members of the Asteraceae family," Phytochemistry, vol. 72, no. 8, pp. 781-790, 2011.

[42] D. B. Silva, L. T. Okano, N. P. Lopes, and D. C. R. De Oliveira, "Flavanone glycosides from Bidens gardneri Bak. (Asteraceae)," Phytochemistry, vol. 96, pp. 418-422, 2013.

[43] D. Fraisse, C. Felgines, O. Texier, and L. J. Lamaison, "Caffeoyl derivatives: major antioxidant compounds of some wild herbs of the Asteraceae family," Journal of Food and Nutrition Sciences, vol. 2, no. 3, pp. 181-192, 2011.

[44] C. Zidorn, E. P. Ellmerer, S. Sturm, and H. Stuppner, “Tyrolobibenzyls E and F from Scorzonera humilis and distribution of caffeic acid derivatives, lignans and tyrolobibenzyls in European taxa of the subtribe Scorzonerinae (Lactuceae, Asteraceae)," Phytochemistry, vol. 63, no. 1, pp. 61-67, 2003.

[45] O. Danino, H. E. Gottlieb, S. Grossman, and M. Bergman, "Antioxidant activity of 1,3-dicaffeoylquinic acid isolated from Inula viscosa," Food Research International, vol. 42, no. 9, pp. 1273-1280, 2009.

[46] Z. Réblová, "Effect of temperature on the antioxidant activity of phenolic acids," Czech Journal of Food Sciences, vol. 30, no. 2, pp. 171-177, 2012.

[47] Z. Haiyan, D. R. Bedgood Jr., A. G. Bishop, P. D. Prenzler, and K. Robards, "Effect of added caffeic acid and tyrosol on the fatty acid and volatile profiles of camellia oil following heating," Journal of Agricultural and Food Chemistry, vol. 54, no. 25, pp. 9551-9558, 2006.

[48] S. Rawat, R. Singh, P. Thakur, S. Kaur, and A. Semwal, "Wound healing agents from medicinal plants: a review," Asian Pacific Journal of Tropical Biomedicine, vol. 2, no. 3, pp. S1910-S1917, 2012.

[49] Y. Song, R. Zeng, L. Hu, K. G. Maffucci, X. Ren, and Y. Qu, "In vivo wound healing and in vitro antioxidant activities of Bletilla striata phenolic extracts," Biomedicine \& Pharmacotherapy, vol. 93, pp. 451-461, 2017.

[50] J. Infante, P. L. Rosalen, J. G. Lazarini, M. Franchin, and S. M. De Alencar, "Antioxidant and anti-inflammatory activities of unexplored Brazilian native fruits," PLoS ONE, vol. 11, no. 4, article e0152974, 2016.

[51] O. T. Agar, M. Dikmen, N. Ozturk, M. A. Yilmaz, H. Temel, and F. P. Turkmenoglu, "Comparative studies on phenolic composition, antioxidant, wound healing and cytotoxic activities of selected achillea L. species growing in Turkey," Molecules, vol. 20, no. 10, pp. 17976-18000, 2015.

[52] A. A. Geronikaki and A. M. Gavalas, "Antioxidants and inflammatory disease: synthetic and natural antioxidants with anti-inflammatory activity," Combinatorial Chemistry \& High Throughput Screening, vol. 9, no. 6, pp. 425-442, 2006. 


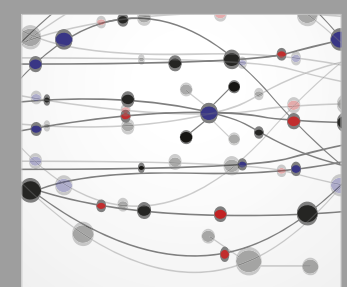

The Scientific World Journal
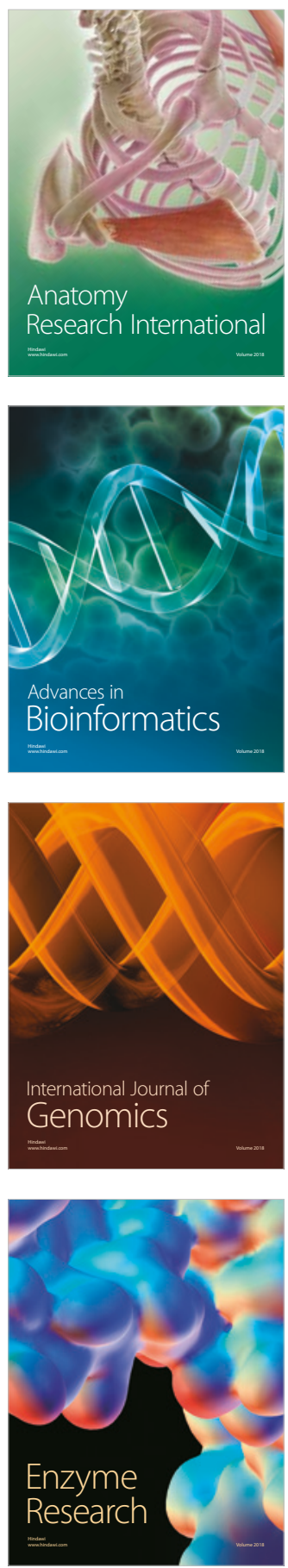
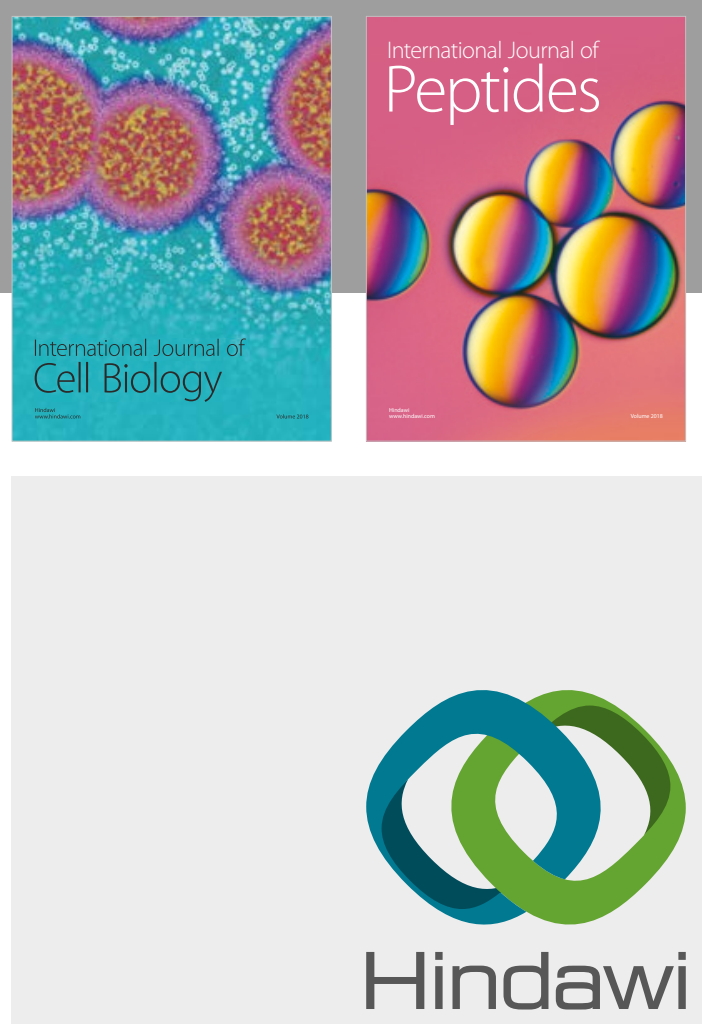

Submit your manuscripts at

www.hindawi.com
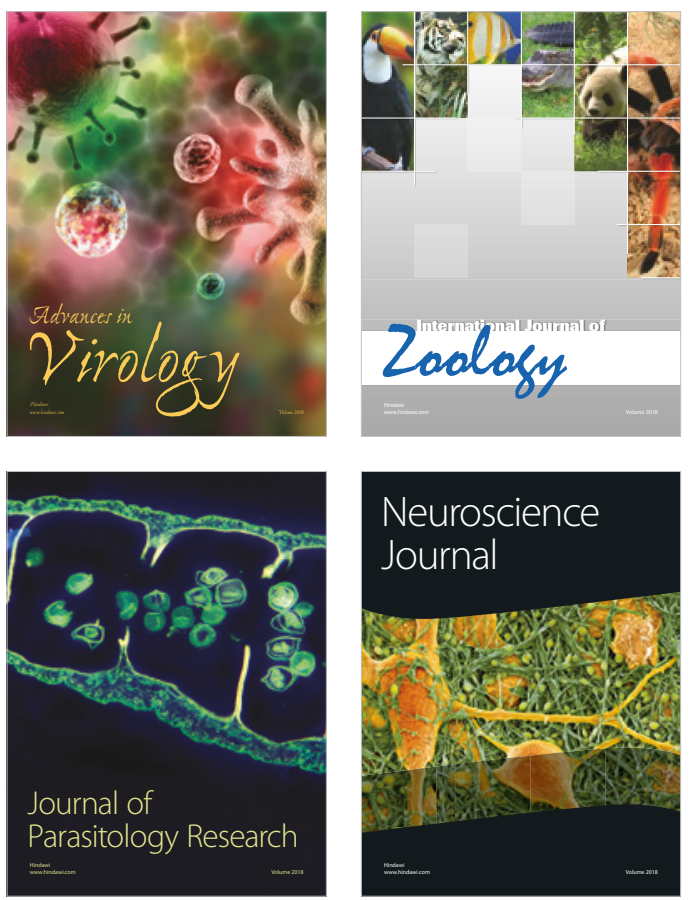
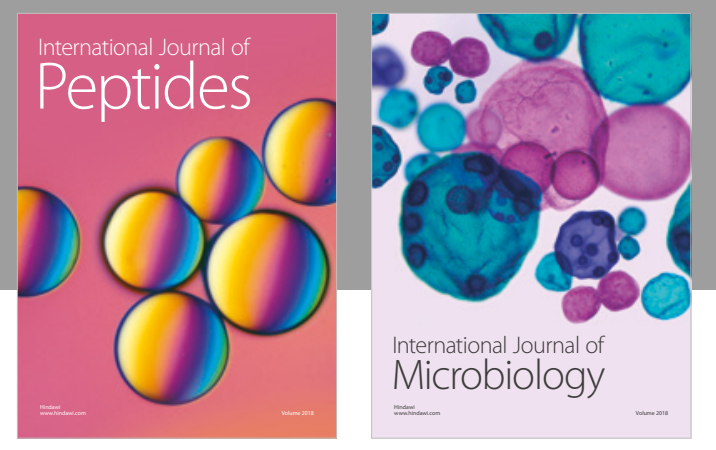

nternational Journal of Microbiology
Journal of
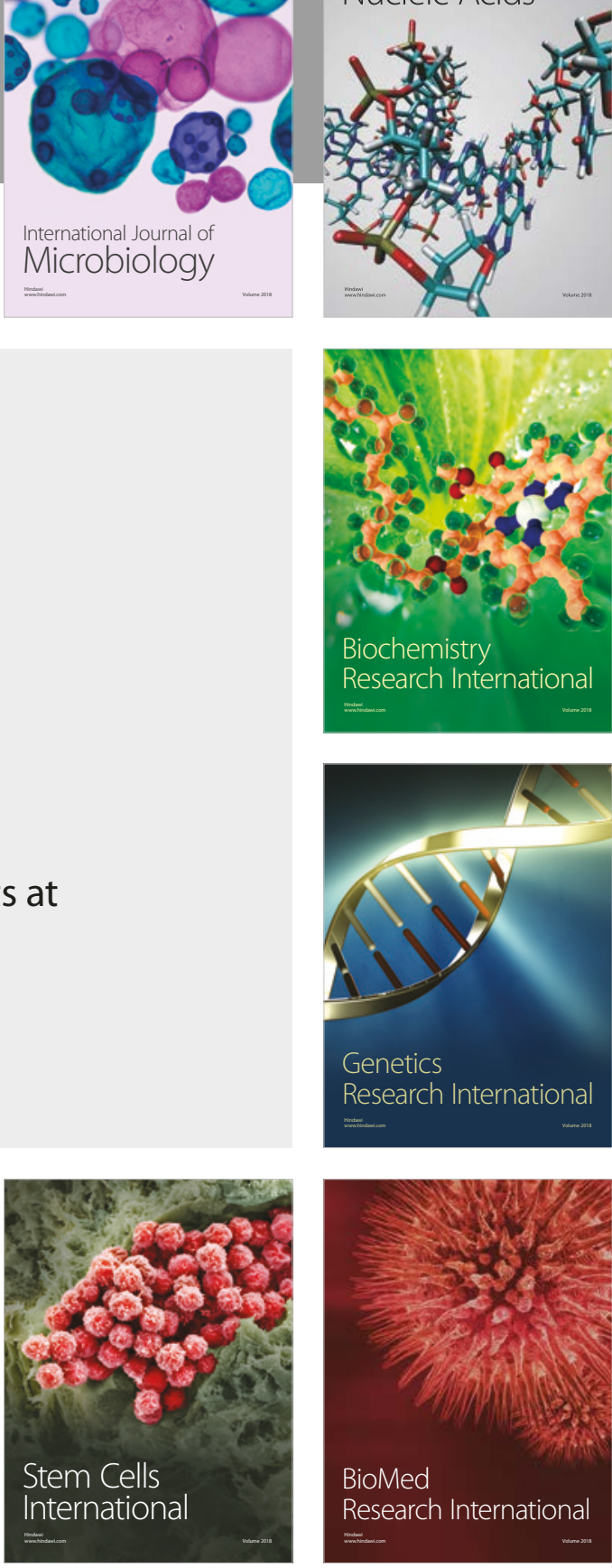
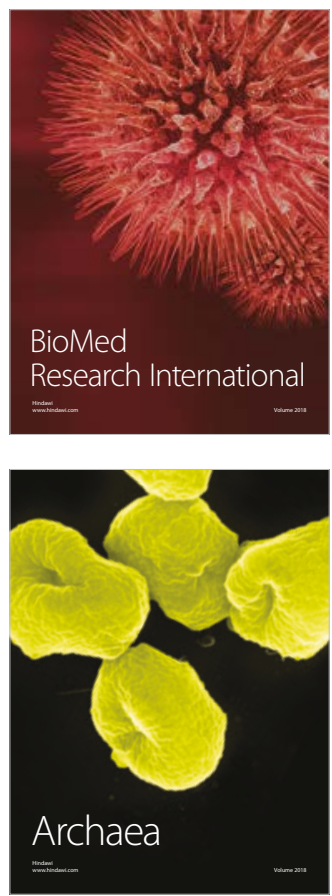